\title{
The Politics of States and Local Governments Creation in Nigeria: An Appraisal
}

By

Adeyemi, o. Oluwatobi

\begin{abstract}
State and local governments are instruments of development aimed at bringing government closer to the people so as to ensure their greater and equitable participation in the process of governance. However, in Nigeria, the pattern of infrastructural development is concentrated in the state and local government headquarters, rather than adopting holistic developmental process, which has engender stiff competition and scramble for local government creation among various groups in the polity..

Against this background, this paper examines the process of state and local government creation in Nigeria from 1960 till date. The study found that state and local government have and become an avenue for obtaining more allocations from the federal government coffer, as well as political representations at the national assembly.

The study presumably hopes to provide useful solution to frequent agitation for creation of more state and local government by recommending that government at all levels (federal, state and local) should be responsive to the aspirations of the people at grassroot so as to reduce further agitation and ensure political stability and development. The methodology employed is qualitative method collections of data.
\end{abstract}

Keywords: State, Local Government, Politics, Amalgamation, Military, Federal Character, Federalism, Government.

\section{Introduction}

Nigeria is a federation of 36 states, a federal capital territory (FCT) and 774 local government areas. To understand the various dimensions of governance capacity at the state and local levels, it's imperative to begin by appreciating the changing federal context within which state and local governments were formed (Barkan, Gboyegan and Stevens, 2001). 
The politics of State creation in Nigeria is as old as the country itself. Nigerian State was a product of 1914 amalgamation of Northern and Southern protectorates by Lord Lugard. There were no concrete objective criteria for the amalgamation except for the administrative and exploitative tendency of the colonial powers. There was no consideration for cultural affinity, none for geographical contiguity, despite the natural and geographical separation by two of Africa's giant rivers, River Niger and River Benue with its confluence at Lokoja (Familoni, 2005:39). For instance, Sir Arthur Richard in (Osuntokun, 1979:98-99) commented on the situation of Nigeria before independence when he depicted thus:

... it is only the accident of British... which has made Nigeria one country. It is still far from being one country or one nation socially or even economically... and politically, there are deep differences between the major tribal groups. They do not speak the same language and they represent different stages of culture.

The statement was corroborated by Tafawa Balewa in (Osuntokun, 1979:98-99) when he observed that:

\section{Since amalgamation of Southern and Northern Provinces in 1914,} Nigeria has existed as one country on paper... it is far from being united. Nigeria unity is only British intention for the country

The slogan, "one country, one nation, one destiny" was and is still a cosmetic attempt to merge into existence a nation without a genuine identity and a common purpose (Familoni, 2005:39). This same kind of opinion was also shared by Muammar Gaddafi when he advised that the country be partitioned into several states. According to him, "the model that best fits Nigeria, which comprises many ethnic groups, is Yugoslavia model, which divided the country into six countries, including Kosovo whose independent has not been universally recognized"' (Ghadafi, 2010:1\&4). Based on the foregoing, it could be inferred that the Nigerian state was founded on a false premise of oneness for the purpose of exploiting her resources. The implication of this is that the Nigerian state is a product of force union. The historical circumstances of her emergence make her an amalgam of divergent people with divergent language, culture, values and beliefs. It is an irony of history that from the moment of amalgamation in January 1914 to date, attempts are still being continuously made to wedge together the divergences so as to have a united, unified and cohesive state (Kolawole (2004:49). It could also suffice to say that ethnic crisis is a fundamental problem in Nigeria and any attempt to solve it cannot ignore the circumstances that led to the antecedent of Nigerian State as an artificial entity (Familoni, 2005). Successive governments since independence have tried to address this problem through states creation, which has resulted into continuous agitation by different ethnic groups. The military rulers of northern origin have capitalized on this to create more state and local government in the north over and above the south; and this was done mainly to strengthen the Northern supremacy over other ethnic groups. For instance, Olasupo (2006:314) revealed the arbitrary creation of local governments during the Babaginda's administration's which formed bases for 1992 election to the National Assembly when he allocated more representation to the North over the South. Oyediran (1997:213) also comments on the situation thus:

By using local government areas as the basic for the constituency of House of Representatives, the administration gave some states with more than double the 
population of other states less members in this arm of central legislature. For example, Lagos State with a population of 5, 6855,781, had 15 members while Niger State (where Babaginda came from) with population of a population of 2,482,367, had 19 member in the House. On the other, Kano State, which had about the same population as Lagos - 5,632,040, had 34members and Sokoto with 4,392,391 population had 29 seats. Ondo state with 3,884,485 had 28 seats and Akwa Ibom, with a population of 2,389,736 had 24 members.

By implication therefore, it was after this election that the regime realized that there were more local governments than the country needed (Olasupo, 2006:315).

At independence in 1960, Nigeria was politically demarcated into three regions, North, East and West, with Lagos as the federal territory. By 1963, the Mid-West region was carved out of the Western region. Ayoade pointed out that, "we started by creating states to redress federal imbalance but ended up with greater imbalances" (Abu 2005:95), General. Gowon tried to reconcile North and South parity by creating six States in the North and six States in the South, but General Murtala Mohammed established the Northern supremacy by creating ten States in the North and nine in the South. General Babangida later consolidates on the disparity in 1989 with eleven states in the North and Nine in the South. The second edition of Babaginda's State creation gave sixteen states to the North and fourteen to the South. In 1996, General Abacha strengthens the Northern lead with nineteen states and seventeen in the South. Over the time therefore, the northern ascendancy has become strengthened (Abu, 2005:96). This mindless proliferation of states and invariably local government informed President Obasanjo comment that:

The number of Local Government areas (LGAs) had also risen steadily from 301 in 1976 to 774 currently listed in the first schedule, part 1 of the constitution of the Federal Republic of Nigeria, 1999. Yet the clamour for creation of more LGAs has not abated. Indeed, as of date, a total of over 500 new LGAs are in the process of being created by various state governments. At the same time, the number of state has tripled from twelve to thirty-six since January 1976 without addition to the land area of Nigeria (Ukiwo 2007) .

Overtime, the North domination over other ethnic group in Nigeria has been established. Apart from perpetuating the North - South imbalance, the creation of states also reduces the political power of the states by making them dependent on the central (federal) government for allocation or grant.

\section{Nigerian State: Conceptual and Theorectical Overview}

The State is a way of regulating human conduct; it orders us not to murder; it punishes us for violation of its order. It is society in its political aspect (Appadorai, 2004:13).

To Morgenthan in (Ikelegbe, 1994:417), a State is synonymous with the compulsory organization of society aimed at the achievement of a monopoly of organized violence for the preservation of peace and order. It provides a framework of the social order; it holds society together. It binds individual to certain uniform rules of behavior which are essential for a harmonious and ordered social life (Appadorai, 2004:14). 
There is no general acceptable definition of State. Anifowose (2008:85) in his own contribution to the discourse define State as the most inclusive organization which has formal institutions for regulating the most significant external relationships of the men within its scope. It is the basic political unit, a group of individuals who are organized in a defined territory for the pursuit of secular common welfare, the maintenance of law and order and carrying out of external relations with other groups similarly organized. From the review of all these definitions, a State serves as an institution for preservation of peace and order; a State prevents violence and crisis within the country.

However, the emergence of Nigerian State could be understood or trace from the standpoint of force theory. Force theory explains that, State is the result of the subjugation of the weaker by the stronger. It holds that the origin of the State is a consequence of the strong establishing their sway over the weak, setting them in a specified territory and arrogating to themselves the power of governing (Akindele et al , 2000:38). Jenks a proponent force theory argued in (Appadorai, 2004:32) that, "historically speaking there is not the slightest difficulty in proving that all political communities of the modern type owe their existence to successful warfare". A State is founded when a leader, with his band of warriors gets permanent control of a define territory of considerable size. This may occur in one of two ways. The leader, after firmly establishing his position as a ruler of his own tribe, extends his authority over neighboring tribes until he comes to rules over a large territory (Appadorai, 2004:33-34).

In line with the above, Nigeria could be described as a product of British suzerainty, forcefully forged together from varieties of ethnic sub-nationalities (Adetoye, 2004:342). It is a State created by forceful domination and imposition rather by a consensus for economic exploitation of her resource by the colonial imperial power.

\section{The Evolution of Nigerian State}

Nigeria comprises over 250 ethnic groups, while Hausa, Igbo and Yoruba are regarded as the major ones. The present political map of Nigeria owes is origin to the activities of British interest and authorities operating in the area during the latter half of the $19^{\text {th }}$ century (Abu, 2005:95). Corroborating the above view, Adesuwa (2011:1) argued that:

\section{The geographical expression today known as Nigeria is a political contraption, an agglomeration of ethnic nationalities cunningly brought together by British imperialists to create a pseudo federation that would pave way for the maximization of economic exploitation of the captive people within geographical environment.}

The need for markets, raw materials and the need to exert political influence overseas led Britain to journey to places as distant as Wikki in the present day Borno and Sokoto in Nigeria (Onlinenigeria, 2011).

Fafowora (2013:64a) observes that, the British colonial policy in Africa was vastly different from the French colonial policy of assimilation that envisioned its colonies as possible French states in future. Lugard and most of his administrative successors in Nigeria did not have such a vision for Nigeria. The scramble for Africa and its ultimate partition among the various European powers provide a clue to 
understanding the nature and motive of the state that emerged in Africa (Agagu, 2004:10). The Africans were neither present at the Berlin Congress nor even consulted about the manner their territories were divided among European powers (Fafowora, 2013:64b) Hence, Nigerian nation is a product of colonial creation. This is so because until 1900, the landmasses known today as Nigeria, existed as a number of independent and sometime hostile national states with linguistic and cultural differences. It is important to state that the Nigerian state falls into the category of nation which Thomas Hobbes labeled as "commonwealth by acquisition" the implication of this is that, the Nigerian state is a product of forced union ((Obasanjo 1980:1; Kolawole, 2004:49)

In 1849, the British Government appointed John Beecroft as the Governor of Bights of Benin and Bonny, his job was to regulate commercial relations commercial relations with coastal city States. Backed by fierce gunboat, he interfered with the internal affairs of these States and process which culminated in the imposition of colonial rule came afoot (Onlinenigeria, 2011). And in 1861 Lagos was proclaimed a crown colony.

Hence with the initiative of the United Africa Company, formed by George Goldie, and through an amalgamation of British firms in 1879, most of the part which became Northern Nigeria was preserved as British sphere to the chagrin of French and German competitors (Onlinenigeria, 2011). The company received a charter to administer it until 1899 when the charter was revoked (Onlinenigeria, 2011). By 1900, the British government took over the control of the Northern region from the company and proclaimed the part the protectorate of Northern Nigeria (Babawale 1998:75). The Colony and Protectorate of Lagos was a separate entity at that time. By 1906, this protectorate of southern Nigeria was amalgamated with Lagos which had been proclaimed a crown colony in 1861. The two were subsequently titled colony and protectorate of Southern Nigeria (Babawale, 1998).

The British effort at securing administrative convenience in the governance of these different ethnic groups led to the amalgamation of the two protectorates in 1914. France and England seized Cameroon from Germany during World War 1, which she administered as part of Nigeria. On October $1^{\text {st }} 1960$ Nigeria became independent nation. A plebiscite was held in the Cameroons in 1961 and Southern Cameroon voted to join the Northern Cameroon. With the separation of Southern Cameroon the external boundaries of Nigeria attained their present form (Abu, 2005:95).

\section{States creation exercises in Nigeria.}

The politics of state creation in Nigeria can be traced to the pre- independent days of Sir Arthur Richards, when as the Governor-General created three regions out of the amalgamated Northern and Southern protectorates in 1945 (Osunde and Alo, 2010). The Nigerian state's creation experiences have been quite dramatic, state re-organization in the country have tended to be cyclical or self-perpetuating with each restructuring merely provoking agitation for further reorganization (Omotoso 2004:102).

Given the fact that the balkanization of Nigeria according to the successive leaders into first, regions and later, states was for economic exigencies; the values which appeared to be considered in creation of Mid- West region. One could not but agree that what followed when military took over was a clear cut from the established norms. The long 
period of military interregnum had made ethnic consciousness and tribal stratification more pronounce in Nigerian polity. For instance, with the military intervention in 1966 came the tribal consciousness that developed into civil war which end product culminated to the slogan, One Nigeria, as adopted by General Yakubu Gowon's administration. This was done in his desperate bid to reunite the country that had been devastated by suspicion engendered by tribal sentiment (Osunde and Alo, 2010).

Ikporukpo observes that, criteria for state creation include ethic affinity; geographical contiguity; population; land area; viability of new and old state; cultural incompatibility and self-determination etc. The capacity of jurisdictional partitioning to rectifying inequalities through the activities of local states is one of the driving forces behind the demand for more states, where the equitable distribution of resource is an explicit objective of spatial engineering (Abu, 2005:96). In Nigeria according the intents are hardly altruistic, noble or patriotic. The main argument advanced in support of partitioning in Nigeria centered on the issue of equity with regard to access to social and economic infrastructure (Abu, 2005). In the same vein, the agitation for states and local governments are seen as a sort of ethnic political economic strategy which considers the number states from each ethnic group as added leverage for a more equitable share of national resources (Omotosho, 2004:101). This statement was corroborated by Obasanjo in when he depicted thus, "in fact there is clear evidence that the creation of local government has been for reasons that not only negate the objectives and principles of the 1976 reform, but, in some cases, are clear expression of patronage by revenue distribution to favour areas or interest group" Ukiwo (2007).

No sooner than the states and local governments are created, then they are caught up in daunting administrative challenges and problems such as poor infrastructural facilities, excessively high wage bills, low level of internally generated revenue, dwindling budgets, allocation of scarce resources to unproductive capital projects, massive corruption and wastage through inflated contracts, outright theft of public money and acrimonious battle over asserts sharing to mention just a few, yet no hope of a stop to the desire for "own state" by the ethnic rivals (Omotosho, 2004:101102).

The original criteria for state creation in Nigeria, according to Suberu in (Omotoso, 2004) was derived from minority opposition to the three region federal structure, which secure autonomy and hegemony for the Hausa-Fulani, Yoruba and Igbo majority nationalities in the Yoruba and Igbo majority nationalities in the Northern, Western and Eastern Region respectively. Larry Diamond quoted in (Omotoso, 2004) rightly observed along the same line:

Ethnic minority fears and grievances centered around obtaining a fair Share of rewards and resources of an expanding economy and states; contract, loan, scholarships, processing plant...minority demands for separate state were based on

the belief actively promoted by their leader that minorities were being cheated in the distribution of those resources by the majority-dominated regional governments.

This was also corroborated by Yahaya, when he identified, linguistic or cultural incompatibility, domination and accelerated development as the reason for state creation. 
The factors of domination and accelerated development are particularly relevant in the Nigeria context. Domination refers to official discrimination in employment, distribution of amenities and official infrastructure facilities (Abu, 2005). So each of the competing groups would stop at nothing to make sure that the balance tills in favor when it comes to creation of states, local government areas or the location of infrastructure or other employment generating scheme. This belief is strong that the military leaders who had taken most of these decisions had exercised their powers under the influence of inducements by groups competing for the use of such discretionary power in their favor (Abu, 2005).

Odinkalu (2011) highlighted three explosive issues in Nigeria's state creation exercise that are conveniently not spelt out. One is political equity in a multi-ethnic country in which ethnic identity often trumps civic identity. The problem is that states are the bases distribution of the federation's assets and liabilities not for generation of it earnings. There are currently only thirty six states and one Federal Capital Territory (FCT) to be shared among 370 ethnic and national groups. These state and local government are enough states to go round the ethnic groups. Therefore, several ethnic groups must coexist within the same state. This creates majorities and minorities within the same state, with attendant claims and counter-claims of domination and subjugation; exclusion and marginalization; indigene and settler. Hence, state creation was supposed to alleviate this problem. Instead, it has deepened it (Odinkalu, 2011).

The second according to Odinkalu (2011) is fiscal prudence. Running states costs a lot of money. States require human assets that must be remunerated and new elite whose appetites must be funded, even before development takes place. This means more overheads and recurrent expenditure for the state that could not raise their own revenue internally, except Lagos virtually all the state depend on federally collected revenue for their for their stipends and overheads (Odinkalu, 2011).

The third is national security, this according to Odinkalu (2011) was initiated by the military regime of General Yakubu Gowon on the eve of the outbreak of the Nigeria Civil War on 27 May, 1967, national security remained perhaps the controlling imperative for state creation under the military. This imperative translated into a need to eliminate the capacity of any of Nigeria's constituent territories to levy war against the center. This may have justified the fiscal dependency of states under the as an objective in itself. In a democratic dispensation, such dependency could itself become a source of national security threat (Odinkalu, 2011).

Since 1954 when the minority groups in Nigeria first demanded from the colonial government, the creation of autonomous divisions, in order to ensure equity and justice in Nigerian federal structure; the demands for the creation of state and local governments by various ethnic groups has become a recurring phenomenon in Nigerian polity till date. What has aggravated this arrant lack of effectiveness, according to Mimiko (2011) was lack objective set of criteria for state creation. Devoid of this, state creation soon became an instrument in political patronage and one designed to enhance the competitive edge of particular tendencies or regimes that become dominant at different points in the historical trajectory. And as long as there are no objective criteria for the creation of State, for so long shall the clamor for new State in Nigeria continue. 


\section{States Creation Exercises in the First Republic}

At Nigeria independence in 1960, the country comprised of three regions. In all these regions, there were unrelenting clamor for creation of more states, particularly by minority ethnic groups (Omotoso, 2000:102). The most serious areas of intense agitation for new state were middle Belt in the North, the Mid - West in the West and Calabar, Ogoja and Rivers in the East. The agitation championed by J.S. Tarka for the creation of a Middle Belt region was perhaps the most celebrated and the most violent during this period (Omotoso, 2004:102). This agitation was able to be silenced using the federal government might. According to Ekwekwe in (Omotoso, 2004) noted that the rationale for silencing this agitation was an attempt by the ruling Northern People Congress (NPC) to entrench the oligarchy of the traditional elite on the indigenous people of the area and its lack of interest in the democratization of the political process of the region. Despite the violence that was associated with this agitation for region, it was not created because NPC in power at the federal level deployed all political machineries to suppress the agitation.

In the Eastern region, the minority group of Calabar, Ogoja and Rivers agitated and demanded for creation of their own region. The National Council of Nigeria Citizen (NCNC), which was the ruling party the region, saw the agitation as anti-Igbo affairs, because of this; it did everything possible to frustrate it. However, it offered some administrative concession like a Regional House of Chiefs, greater and an increased number of functions for local government (Omotoso, 2004).

The creation of Mid-Western Region in 1963 was the first major state creation exercise carried out at post - independence Nigeria. Pressure for creation of the region out of the Western Region had gather momentum under the effective leadership of the Mid-West State Movement (Omotoso, 2004). The region was eventually created on August 9, 1963. In order to deny the Western House of Assembly the constitutional right of determining whether the region should be split into two, the motion for creation of Mid-West Region was initiated when the Western Region was being administered by an administrator. The motion was passed by federal legislature and subsequently by the legislature of the East and the North, but not by Western legislature which had been put out of existence by an act of the federal government (Dudley 1966:65-66). For instance Akintola quoted in (Omotoso, 2004), a former Premier of the Western Region opined thus:

If it is good to create states, why are state not created in the North ... in the East? Why should the West be single out for this operation?

However, the creation of a Mid-West region from Western region in 1963 did not arise from a genuine concern by the government for the interest of the minorities. Rather, the exercise was part of a vindictive campaign by the ruling federal coalition parties - the Northern People Congress (NPC) and Eastern- based National Council of Nigerian Citizen (NCNC), to destroy the main federal opposition party, the Action Group (AG), while rejecting the same proposal in their respective home region (Omotoso, 2004:104, quoted Suberu 1998:10). This was also corroborated by Adejugbe (2002:1) according to him the Northern People Congress (NPC) took the advantage of the factionalization of 
the Action Group (AG) to carve out the Mid-Western region from the Western region in 1963. This exercise was done mainly to curtail the influence of Action Group (AG) in the West.

\section{States Creation Under Military Rule (The Gowon Era)}

On January 15, 1966 the Government of Tafawa Balewa was overthrown through a military coup. Major General J.T.U. Ironsi became the military head of state but his regime was short-lived as his government was also overthrown on July 29, 1966. The Military Head of State Major General J.T.U. Ironsi and his host Lt. Col. Adekunle Fayuji the then military of Western region, were captured and brutally executed at Ibadan. This change in government led to the emergence of Lt. Colonel Yakubu Gowon as the Head of State. After the second coup there was wanton killing of Easterners in the Northern Nigeria. The pogrom coupled with the incessant home-call of Ibos to East by Odumegwu Ojukwu, most Ibos living outside the Eastern part of Nigeria left for East. That gory situation enabled Lieutenant Colonel Ojukwu the then military Governor of Eastern region to mobilize for war against the federal government (Adejugbe, 2002:3). In order to politically incapacitate Ojukwu's secession bid to create an independent Igbo homeland (Biafra), on May 27, 1967, Gowon announced the creation of twelve states, three of which were carved out of the Eastern region. According to General Gowon, the creation of state must be done first, to remove the fear of domination. It would be recalled that the establishment of twelve state framework in 1967 derived from political ascendancy of new military - based ethno - political coalitions and the urgent need to under - cut the imminent secession of oil rich Eastern region from the federation (Ojo and Adebayo 2008). Gowon's twelve states structure was obviously design to undermine Ojukwu's secessionist agenda. According to Gowon (1968:2):

...in the event of Lt. Col. Ojukwu carrying out his threats of secession this will be a clear signal in the first place to create a COR State for the protection of minorities in Eastern Nigeria who we know do not want to depart from the rest of the country.

Gowon in his Broadcast quoted in Omoigui (2011) to the nation on May 27, 1967 also declared thus:

As you all aware Nigeria has been immersed in an extremely in an extremely grave crisis for almost eighteen months. We have now reached a most critical phase where what is at stake is the very survival of Nigeria as one political and economic unit. We must rise to the challenge and what we do in the next few days will be decisive...

As I have warned before, my duty is clear-faced with this final choice between action to save Nigeria and acquiescence in secession and disintegration... I have assume full powers as Commander-in-Chief of the Armed Forced and Head of the Federal Military Government for the short period necessary to carry through the measures which are now urgently required... To this end, therefore, I am promulgating a Decree which will divide the Federal republic into Twelve States. The twelve states will be six in the present Northern Region, three in the present Eastern Region, the Mid-west will remain as it is, the Colony Province of the 


\section{Western Region and Lagos will form a new Lagos State and Western Region will otherwise remain as it is}

Eliagwu (1986:102) observed that, the exercise was aimed at diluting support from succession. The exercise may also have been carried out to mollify fastening complaints about the domineering tendencies of the monolithic North in a lopsided federal structure. The Midwest region was left intact, while the North like the South was fragmented into six states. In essence, the 1967 reorganization did not only end the structural imbalance engendered by the disproportionate size of the North; it also created a federal structure in which the interests of minority ethnic groups and indeed the nation at large, could no longer be abused by any ethnic majority group (Ojo and Adebayo 2008). All of this was of course, consistent with the military's emerging commitment at manipulating the state structure to augment the hegemony of center and tame the divisive tendencies inherent in Nigeria's cultural diversity (Suberu, 1998:281282).

\section{States Creation Under Murtala Mohammed's Regime}

The clamoring for creation of more states started shortly after the end of the civil war in 1970. There were renewed agitations across Nigeria as more Nigerians demanded for state creation of their out of the existing ones. Agitation for new state became a political issue and the newly emergent politicians used the issue to canvass for votes and political support in the bid to gain political power. The inability of Gowon's administration to create more state, for a second time, was one of reasons for overthrowing his government. Murtala's administration indicated its desire to create more state in the country, and the regime set up a panel on the issue of state creation and boundary adjustment. The panel was headed by Justice Ayo Irikefe with five other members and inaugurated on August 7, 1975 with specific terms of reference to:

(1) Advise on the delimitation of such states;

(2) Advise on economic viability of the proposed states;

(3) Advise on the location of administrative capitals of the proposed states; and,

(4) To receive and examine written representations from individuals, groups, organizations or associations who may have views on the desirability or otherwise of creating states in particular areas (Ministry of Information, 1976).

The report of the Commission informed the basic for creation of nineteen states on February 1976. In announcing the states, General Murtala Muhammed emphasized three basic considerations that informed his decision, the need to ensure even development within a federal structure of government; the need to bring government nearer to the people; and the need to make the creation of new states as one time operation that would minimize future agitation for new states (Omotoso, 2004:106, see also Muhammed 1976:49).

The 1976 states creation exercise was implemented also in the wake of phenomenal expansion in federal petroleum export revenue allocation arrangements that enthroned inter-state equality as the preeminent standard of financial devolution (Ojo and Adebayo 2008). 
The restructuring has some basic elements. First, owning to the explicit association of state- creation with the devolution of central revenue, there was an official commitment in making the state as equal in population as possible, this was in order to ensure some per capital equity in access of territorial communities to federal revenues. Consequently, many statehood requests were rejected on no other ground than their relatively limited population, which did not justify any reorganization (Ojo and Adebayo, 2008). The palpable casualties of the policy were the numerically disadvantaged ethnic groups. In essence, while as many as six of the twelve states created in 1967 were majority controlled units; only about seven of the nineteen states in 1976 could be regarded as ethnic minority states (Osaghae, 1986:158-160). Moreover, as regards federal balancing, the nineteen states structure consisted of ten and nine states in the North and South respectively, thereby overturning the pre-existing equality between the admittedly more populous North and apparently smaller South and regional inequality in distribution of states has remained an important source of contention in the Nigerian federation (Ojo and Adebayo, 2008).

The Igbo and ethnic minorities were not so happy about the 1976 exercise. They were opinion that the exercise put them at a great disadvantage in the Nigerian federal structure (Omotosho, 2004). Chinua Achebe echoed the bitterness of the Igbo elite, according to him; the exercise was a sort of conspiracy by Murtala's regime against Igbo. This is because the Igbo competitor in the Nigerian Federalism Yoruba were dominant in five states while Igbo had only two states (Omotoso, 2004, see also Achebe 1983:49)

Another related feature of the 1976 reorganization rightly observed by Suberu (1991) was the explicit transformation of the rationale for state - creation from its original role. As a sop for minority fears into a scheme foe dissemination of central revenue (derived mainly from the Southern ethnic minority communities) to predominantly ethnic majority populations. Henceforth, state creation ceases to be a vehicle for extending political and economic self governance to distinct ethnic communities. Rather, it became an administrative strategy for the devolution of federal largesse to an omnibus and amorphous array of territorial communities and coalitions (Suberu, 1999).

\section{1987 and 1991 Babangida's States Creation Exercises}

With the birth of General Ibrahim Babangida administration on August 1985, states' agitators demanded for the creation of more states. The Babangida's administration set up Political Bureau headed by Dr. Samuel Cookey and was mandated to coordinate the debate on the country's political future. In carrying out its assignment, the Bureau was presented with specific requests and general suggestions for new states. This was extensively discussed in its report as one of the contentious or special themes in Nigeria political debate (FRN 1987:168-181). Also, the Bureau was presented with different proposal on how additional states could be created in the country. The Bureau in its report recommended six additional states in the interest of fair play and justice. On September 23, 1987 General Ibrahim Babangida, bases on the five-man committee report, announced the creation of two more states, Katsina and Akwa-Ibom making it twenty one states in Nigeria. 
The exercise according to Omotoso (2004) sought to complete the unfinished business of the 1976 state creation. This is because the creation of Akwa Ibom had been explicitly recommended by Irikefe Commission, while Zaria-Kastina imbroglio in Kaduna state and the attendant agitation for the separation of the two communities have become extremely strident even before the military disengagement in 1979 (Ojo and Adebayo 2008). On August 27, 1991, Babangida announced the creation of additional nine states to make the total number of the states in federation thirty. While the 1987 reorganizations genuinely appeared to be in national interest, as claimed by General Babangida, the 1991 reform underscored both the continuing popular pressure for new states and Babaginda's desired to exploit these demands to promote his personal rulership project (Amuwo, 1995). The demands emanated largely from Igbo intelligentsia and forcefully and persuasively, that they have been economically short- changed and politically marginalized in the various reorganizations of the federal structure since 1967 (Ojo and Adebayo, 2008). Babaginda responded to this particular grievance by creating two new Igbo states - Abia and (new) Anambra and locating the capital of the third state, Delta in Igbo city of Asaba.

Nevertheless, the six remaining states created in 1991 gave satisfactory to distributive pressures emanating from Hausa/Fulani and Yoruba sub-groups (Jigawa, Kebbi, Osun) or responded to the need to extend political and economic decentralization to geographical large, administrative unwieldy and or culturally incompatibles areas (Kogi, Taraba and Yobe) (Ojo and Adebayo op.cit). However, the location of five of the nine states in the North compounded the problems of geopolitical balancing vis-à-vis the distribution of states. The new thirty six states structure comprised of sixteen states in the North against fourteen in the south. The minorities' ethnic groups were also short- changed; they had only twelve out of the thirty states. According to Johnson (1991) the creation of the nine new states and the accompanying reorganization of the localities were done in a precipitate and prejudiced manner. Consequently, rather than promoting national integration, the re-organizations provoked an unprecedented orgy of protests, demonstrations and riots involving tens of fatalities.

\section{States Creation Exercises Under General Abacha's Regime}

General Sani Abacha became the head of state, through a palace coup in November 1993, it was a period when the Nation was experiencing political crisis as a result of annulment of June 12, 1993 General Election. As a way of resolving the problem of the country, the regime set up the National Constitutional Conference (NCC). State creation was one of the issues that dominated the debate of National Constitutional Conference (NCC) set up by the Abacha's government. Unfortunately, NCC found it difficult to resolve this issue because of the member's conflicting interests. It later transferred the responsibility to the Abacha's government. In the view of this, General Abacha inaugurated Chief Arthur Mbanefo - led committee on the creation of state and local government on December 13, 1995 (Omotoso, 2004). On the assumption of office, the committee requested for submission of memorandum from members of the public and set January 15, 1996 as the dead line. At the end of the day, 2,369 
demands for local governments and 280 boundary adjustments were made. The committee received a total of seventy two requests for states (Ojo and Adebayo, 2008).

The committee submitted its report, in which it made a number of recommendations. The report of the committee, unlike Irikefe Panel was neither publicized nor published. On October 1st, 1996, General Sani Abacha announced the creation of new six states namely, Bayelsa, Ebonyi, Ekiti, Gombe, Nassarawa and Zamfara, making the total number of states in the federation thirty six.

\section{State and Local Governments Creation Under Democratic Dispensation (1999- 2013)}

The creation of new local government under Obasanjo's administration has been problematic. Five state namely, Ebonyi, Kastina, Lagos, Nasarawa and Niger had created new local governments and went ahead to conduct election for the councils citing section 7(11) of the 1999 constitution as their enabling power. This generated several conflicts between the federal government and the concern states as the federal government claimed it would not release funds from the federation account to LGAs that are not listed in the constitution while this non-release of funds forced the concerned state governments to abolish the new LGAs, Lagos state government was adamant, risking non release fund for LGAs for several months. Lagos was able to sustain the resistance because it is a state with largest non - oil internally generated revenue; Lagos invariably challenged the action of Federal government in the Law court and won at the Supreme Court, the withholding allocation was released during Yaradua's administration.

However when National Assembly called for memorandum for state creation from interested ethnic groups and people, it probably got more than it bargain for, as different groups from different states across the country visited the National Assembly with records, facts and figures of how they deserve to be the beneficiary of new state to be created.

However a cursory look at some of the states being agitated for will reveal a fundamental inherent defect that has hitherto plagued the polity, which is the fact that more than 85 percent of the states of federation are not financially and economically viable. For instance, in Enugu state, the people of Enugu North Senatorial District have been clamouring for the creation of Adada state, also in Abia where the people are agitating for their own state. In the North, several groups have continued to clamor for new states. In Kogi alone, the minority groups are agitating for creation of Okun and Oya states. In Benue the Idoma ethnic groups are also agitating for creation of Idoma state out of present Benue state. Other with agitations for the creation of new states includes Bauchi state, a state with just twenty local governments.

The region with perhaps the most elaborate agitations is South West zone, where more than three groups are agitating for different states in the same state. In Oyo state, agitations have been fierce for the creation of Ibadan state, New Oyo state and Oke Ogun state; all from the current Oyo state whose internally generated revenue have been absurdly low given its size and population. Also in Ogun state, the people of Remo and Ijebu have both been at the head of agitation for separate states. Agitators for a new 
state have also emerged from the present Osun state which was carved out of Oyo state in I991, as the people of Ife are agitating for creation of Oduduwa state.

The House of Representative Adhoc Committee on the review of the 1999 Constitution in their report recommended that there would be no creation of new States Ameh, (2013:2; Alli, 2013:4). Ameh, (2013:2) further explains the situation thus:

The committee received requests for creation of States running into more than 35. None of the requests submitted to the committee complied with the procedure for the creation of new States outlined in section 8 of the constitution. Accordingly, the committee was unable to treat any of these requests. The committee however recognizes that the existing provision in the constitution for the creation of new States is unclear and cumbersome.

The committee therefore rejects all the proposals on the creation of new States, with this development the agitation for States and Local Government will be on hold for now.

It is therefore unclear whether some of these groups clamoring for creation of new states have not put into consideration the financial imperative as the mean of survival and provision of goods and services for the citizen of their states.

\section{Politics Of States And Local Governments Creation}

The deliberate misuse of power to alter the political landscape of Nigeria is by no means restricted to state creation. Even more curious is the choice of skewed location as state capital (e.g. Asaba, Dutse, Akwa etc) that were done due to whims and caprices of the then military occupation (Abu, 2005:98). According to Femi Mimiko, state creation has not only failed to solve the problem of ethnic minority rights, but it has also become a veritable instrument with which a string of unitarist leaders had dealt a fatal blow to Nigeria federalism (http://www.nigerdeltacongress.com).

However, the military, especially those of Babaginda's and Abacha's regimes made local government a political game between themselves on the one hand and their acolytes on the other. The regime of General Babaginda, in May 1989, created 149 new LG areas while between August - September 1991 he announced the creation of additional 140 local government areas, bringing the total number of local government councils, as at that time, to 589. Under General Abacha, more local governments were further created - 185- and these brought the total number of local government in the country to 774 (Olasupo, 2006:310, Oyediran, 1997:212).

Local government according to Natufe (2006) has been established arbitrarily across the country. The military bequeathed the Fourth Republic with 774 local government councils, most of which were established to satisfy parochial political interests without regard to their economic viability, commenting on this phenomenon, Ayo Opadokun quoted in (Natufe, 2006) rightly observed thus:

Lagos state at the close of the First Republic had four political divisions while old kano had two political divisions. Lagos today has 20 councils in the constitution. Jigawa has been created out of old kano. The new kano has 44 council while Jigawa has 27 . In the First Republic, Lagos double that of old kano, which now has 71 council while Lagos has $20 \ldots$ similarly we recall that while 
Bendel state had 19 local government councils in the second republic, the military created 25 in Delta and 19 in Edo when these states were created out of defunct Bendel state in 1991. This is replicated across the country by the Nigerian government.

According to him, state creation has become an albatross squeezing the life of the Nigeria polity. Initially it was a demand of the minority ethnic groups to extricate themselves from the oppressive rule of the majority ethnic group in the old Eastern, Northern and Western regions; has now become a political instrument of self balkanization by majority ethnic groups in their quest for balance of power. For instance, Natufe, (2006) rightly reported:

In the creation of states in Nigeria, the Igbo have been marginalized. Up till today, the South East geo-political zone is the only zone with five states, while others have six a piece and a zone, North West has seven states. Igbo are also short-changed in the distribution of Local Government areas. Since the inception of the fourth republic The Igbos has been agitating for an additional state on the grounds of fairness and equity vis-à-vis Yoruba.

The Lagos case has been raised by Southern elites who have since 1990s agitated against so-called northern domination. It is alleged that successive "northern" military rulers favored the North in the creation of states and local government (Ukiwo, 2007). The Southern elites therefore, insisted that central to the resolution of National Question is restructuring of the "unbalance" federation. As Table 1 show, the local governments are unevenly distributed across geo-political zones. The North West zone has a quarter $(24 \%)$ of the LGAs in the country while other five zones have between $12 \%$ and $18 \%$. However, the Table below shows the distribution of local government councils by geopolitical zones

TABLE 1: DISTRIBUTION OF LGAs BY GEOPOLITICAL ZONES

\begin{tabular}{|c|c|c|c|c|}
\hline ZONES & $\begin{array}{c}\text { NO OF } \\
\text { LGAs }\end{array}$ & $\begin{array}{c}\% \text { OF } \\
\text { LGAs }\end{array}$ & $\begin{array}{c}\text { POPULATION IN } \\
\text { MILLION }\end{array}$ & $\begin{array}{c}\text { \% IN } \\
\text { NATION } \\
\text { POPULATION }\end{array}$ \\
\hline $\begin{array}{c}\text { North Central } \\
\text { including Abuja }\end{array}$ & 120 & 15.5 & 12.5 & 14 \\
\hline North-East & 111 & 14.3 & 11.9 & 13.4 \\
\hline North-west & 186 & 24 & 22.9 & 12.1 \\
\hline South-East & 95 & 12.2 & 10.8 & 15.1 \\
\hline South-South & 123 & 16 & 13.3 & 19.6 \\
\hline South-West & 139 & 18 & 17.4 & 100 \\
\hline TOTAL & 774 & 100 & 88.8 & \\
\hline
\end{tabular}

Source: compiled from constitution of the Federal Republic of Nigeria (1999)

The degree of compactness as Omojola and Fasona highlighted in Abu (op.cit:99) is particular acute in the homelands of the three major ethnic groups that have over the years produced key military officers responsible for the series of jurisdictional partitioning in Nigeria. In order severity we have Hausa-Fulani (Kano-region) Yoruba and Igbo. Even more bizarre is the violation of the criterion of geographical contiguity 
(Table 2). Their geographical distribution among the major geo-political poles has not gone unchallenged. This is because, state and local government form the pigeon hole / framework for the allocation of national revenue that came mainly from petroleum that is domiciled in the homeland of the minority groups in the Niger Delta region (Abu 2005:99).

TABLE 2: NON-CONTIGOUS LGAs IN NIGERIA

\begin{tabular}{|l|l|l|l|}
\hline STATE & LGAS & HEADQUARTER & CONTIGUITY \\
\hline ANAMBRA & DUNUKOFIA & UKPO & 2 \\
\hline DELTA & BOMADI & BOMADI & 4 \\
\hline DELTA & ETHIOPE EAST & ISIOKOLO & 2 \\
\hline DELTA & ISOKO NORTH & OZORO & 2 \\
\hline KEBBI & $\begin{array}{l}\text { WASAGU } \\
\text { DANKO }\end{array}$ & RIBAH & 2 \\
\hline LAGOS & IBEJU-LEKKI & AKODO & 2 \\
\hline NIGER & EDATI & ENAGI & 2 \\
\hline YOBE & BARDE & GASHUA & 2 \\
\hline ZAMFARA & MARU & MARU & 2 \\
\hline
\end{tabular}

Source: $A b u$ (2005:99)

Allegation of insider dealing and favoritism also characterized the choice of state and local government headquarters in state and local government creation in Nigeria. For instance, in 1991, the Babangida's administration created Delta state as one of the nine new states. However, against the expectation of the proponents of the state, some parts of the Benin province were joined to Delta province to make up the new State and the headquarter was located in Asaba which was under Benin province. There were protests against the composition of the state and its capital because it was widely believed that Asaba was chosen as the capital because it was the hometown of the military president's wife.

These numerous resultant artificial boundaries have generated several crises. These boundaries in several cases had ended up dividing people of the same cultural affinity; some were merged with traditional hostile neighbors in the strange wedlock (Abu 2005). Examples are, Jos North and Jos South local government in Plateau State, Ife - Modakeke in Osun state, Zango-Kalaf crisis in Kaduna state and the AguleriUmuleri in Anambra state among many others. Communities at this level of government are literally at war over trivial issues such as local government headquarters, boundary adjustment and co-habitation of tribal or ethnic groups in the same local government. For instance, much, disappointed characterized the creation of local government in Delta state in the year 1996. Warri was divided into two local government areas, Warri South and Warri North LGAs. Against the expectation of Ijaw that the new LGA would be called Nein Ibe LGA and its headquarters situated in Oporama, an Ijaw town, koko and Itsekiri town was announced as the headquarter of the new LGA. However, in October 1996 when Abacha's regimes announced the creation of six states and 138 local government areas, and the headquarter of the new local government area created in Warri was Ogbe-Ijoh, believed to be an Ijaw community. The Itsekiri therefore protested and the local government headquarter was subsequently relocated to Ogidigben. It's 
against this background that Ijaw allegedly launched attacks on Itsekiri communities as hundreds of lives were lost and Ijaw youths allegedly destroyed and occupied about twenty five Itsekiri villages (Ukiwo 2007).

The foregoing discussion offer insights into some of the consideration that inform the creation of local government area and such decision which often is taken in the name of decentralization have resulted to violent conflict in Ife/Modakeke, Osun State, Tafawa Balewa in Bauchi state, Umuleri-Aguleri in Anambra state, ObaAkoko/Isua in Ondo state and Warri in Delta State .

\section{Policy Lessons And Recommendations}

The critical factors in the failure of the modern African countries have been the inability of these nations to analyze and provide solution to institutional ills which may be cultural, political, and economical. Most of these Africa countries operate systems and institution that exist as a byproduct of colonial rule that were design to create rivalries and distrust among groups (Nyan, 2010).

African countries including Nigeria have not successfully addressed these social ills and implemented a collective strategy that will identify and eradicate these contradictions and failed policies to benefit their countries. Nigeria still suffer from fundamental nation building issues such as wealth and resource distribution, poor infrastructure, ethnic and religious conflicts and failed governing institutions (Nyan, 2010).

With 36 states and 774 local government councils, the polity is still littered with agitation for more states and local government councils under the pretext of bringing government closer to the population. While it is common knowledge that less than $15 \%$ of Nigeria's 36 states are economically viable, the demand for states (and local government) creation continues to gain momentum (Natufe, 2006).

How will Nigerian State address these fundamental problems? Is by creating more State?

One of the unresolved fundamental problem that is confronting Nigerian state since her independence in 1960 is the continued agitation for creation of more states. Despite the fact that the country has been restructured six times, agitation for the creation of new states has persisted and intensified up till date.

The solution to this problem lays in what Suberu (1998:292) calls the creation of institutional and fiscal resources and thus the expansion of national cake. Indeed, the national cake is really shaking without any attempt to bake new ones making us a nation of consumer and not producers.

Omotoso (2004) also observed that, if government at all levels (federal, state and local) are responsive to the aspirations of the people and can ensure political stability and development agitation for state creation world likely become considerably reduced and national development agenda enhanced.

Government and the citizens must come together to establish a new common sense of civil identity which guarantee total loyalty to the State rather than an ethnic group or a geo-political zone, when this is done, Nigerians will begin to see themselves as one nation. 
The Federal Character Principle which guarantee equal representation of all States of the federation and geo-political zone in the sharing of political power, offices and in the conduct of government business must encourage so as to prevent one tribal group from dominating other tribe in political appointments and government agencies.

There is need for policy framework or institutional mechanism that will encourage inter-groups, inter-tribes, inter-religions relationship within the polity, the traditional rulers and religious leader should not be left out in this crusade.

Finally, according to Arowolo (2008) the major purpose of creating local government is to bring developments to the grassroots. In order to perform adequately, there is need for local councils to have a strong economic base. In this connection, it is suggested that statutory allocations to local council be reviewed upward. In addition to that, councils' shares of federation account to be released to them directly to avoid lateness in the payment of salaries and arbitrary deductions by the state government.

\section{References}

Abu, A. (2005) 'The Spatial Imprint of Corruption in Nigeria" in Olurode Lai and Anifowose R. (Eds) Rich but Poor, Corruption and Good Government in Nigeria, Lagos: Faculty of Social Science, UNILAG.

Adejugbe, M. A. (2002) "Introduction" in Adejugbe, M. A (ed) Perspectives on Nigeria's

Fledgling Fourth Republic, Lagos: Malthouse Press Limited

Adesuwa, S. (2011) Yoruba Yesterday, Today and Tomorrow. Paper Presented on Olojo

Festival 2011 Cultural Lecture Series, at Hilton Hotel, Mayfair Ile-Ife, On 26 $6^{\text {th }}$

October.

Adetoye, D (2004) “The State, Bureaucracy and Corruption in Public Offices: The Nigerian

Phenomenon" in Agagu, A. A \& Ola, R. F. (eds) Development Agenda of the Nigerian State, Ibadan: Fiag (Nigeria) Publisher.

Adujie, P. (2009) Looming or Impending and Political Crises over Local

Government Creation (www.nigeriavillagesquare.com)

Agagu, A.A (2004) “The Nigeria State and Development: A Theoretical and

Empirical Exploration" in Agagu A.A and Ola ROF (Eds) Development

Agenda of Nigerian State, Ibadan: Flag Nigeria Publisher.

Akindele, S. T., Obiyan, S. A \& Owoeye, J (2000) The Subject Matter of Political Science,

Ibadan: College Press \& Publisher Ltd

Akintola, L. (1962) Western House Assembly Debates, Official Report 11 th

Session, Ibadan: Government Printers Cols.

Alii, Y (2013) "Panel Advises Senate: Don't Create New States" The Nation, March, 26.

Ameh, J (2013) “Reps' Panel Want Immunity For President, Governors Removed”, Punch, July, 5

Appadorai, A (2004) The Substance of Politics, New Delhi: Oxford University Press

Arowolo, D. (2008) "Local Government Administration and the Challenges of Rural

Development in Nigeria" (bttp:// darearowolo.articlebase.com/)

Ayoade, J.A. (1997) "Nigeria and the Squandering of Hope" in an Inaugural

Lecture, University of Ibadan.

Barka, J. D and Gboyega, A. (2001) "State and Local Governance in Nigeria". Accessed on

September 28 ${ }^{\text {th }}, 2011$ at (http://info.worldbank.org/etools/docs/library/ 5783)

Diamond, L. (1983) Class, Ethnicity and the Democratic State: Nigeria 1950-

1966, Comparative Studies in Society and History 25. 
Eliagwu, J.I (1986) Gowon: The Biography of a Soldier State Man Ibadan:

West Books Publishers Ltd.

Fafowora, D (2013a) "Lord Lugard and the 1914 Amalgamation of Nigeria" The Nation, February 28.

Fafowora, D (2013b) "Lord Lugard and the 1914 Amalgamation of Nigeria" The Nation, February 14.

Federal Republic of Nigeria (1987) "Report of Political Bureau” Lagos: Federal

Government Printer.

Johnson, Y. (1991) "New State: Harvest of Mixed Feeling”, Sunday Tribune, Ibadan, September 8, Ibadan.

Idahosa, S. A. \& Idris, I (1995) "The Concept and Nature of Politics" in Ikelegbe, A. O (ed)

Politics and Government: An Introductory and Comparative Perspective, Benni: Uri Publishing Ltd

Kolawole D. (2004) "Nigeria: The Struggle for Democratic Consolidation in a

Post-Colonial State" in Agagu A.A and Ola R.O.F (Eds) Development Agenda of Nigerian State, Ibadan: Fiag Nigeria Publisher.

Onlinenigeria (2011) "Nigeria Creation and History- Online", accessed on September $28^{\text {th }}$,

2011 at (bttp:// www.onlinenigeria.com/politicalHistory.asp)

Mimiko, F. (2011) "Before New States get Created"_Accessed on September 28 $8^{\text {th }}, 2011$ at

(http://www.nigerdeltacongress.com/barticles/before new states get created.htm)

Natufe, O.I (2006) Nigeria's Presidency, the Issue (http:/ / wmw.okpention.org)

Nyan, G. (2010) "New State Creation in Nigeria" Accessed on September 28 $8^{\text {th }}, 2011$ at

(http:// afripol.org/gideon-nyan/item/148-new-states-creation-in-nigeria.html)

Obasanjo, O. (1981) My Command Ibadan: Heinemann

Obasanjo, O. (2003) "Address Presented to the Inauguration of The Technical

Committee on the Review of the Structure of Local Government Councils", Abuja, June 25, 2003 (www.nigeriafirst.org).

Odinkalu, C. A.(2011) "Nigeria: Re- Thinking State Creation" Accessed on September 28 ${ }^{\text {th }}$,

2011 at (bttp:/ / allafrica.com./stories/201108090261. btml)

Ojo, E. O. and Adebayo, P. F. (2008) "The Politics of State and Local

Governments' Creation and Nigeria's Search for Geo-Political Balancing” in An

International Multi-Disciplinary in Journal African Journals Online, access at

(www.ajol.info.org).

Olasupo, F. A (2006) Nigeria: “The Functional Relationship between the Regions and Local

Government", in Oladimeji Aborishade and Isiaka Aransi (eds) State and Local Government in

Nigeria: The Changing Scene: Charlotte: Catawba Publishing Company

Omoigui , N. (2011) “ Gowon's Broadcast to the Nation- May 27, 1967” accessed on

September $28^{\text {th }} 2011$ at (bttp:// www.dawodu.com/gowon.htm)

Omotoso, K (2004) "The Nigerian State and The Problem of State Creation" in

Agagu, A.A and Ola, R.O.F (Eds) Development Agenda of the Nigerian

State, Ibadan: Fiag Nigeria Publisher.

Osaghae, E. E. (1986) "Do Ethnic Minorities Still Exist in Nigeria?” Journal of

Commonwealth and Comparative Politics, Vol. 24, No. 2.

Osunde, O. and Alo, A.S. (2010) "Politics of State Creation. Is Soludo Right?"

June 13 (bttp:/ / www.tribune.com).

Osuntokun, J (1979) "The Historical Background of Nigeria Federalism" in A. B. Akinyemi,

P. Dele Cole \& Walter Ibekwe Ofanagoro (eds) Reading on Federalism, Lagos:

Nigerian Institute of International Affairs

Oyediran, O. (1996) “The Reorganization of Local Government” in Larry Diamond, A. Kirk-

Green and Oyeleye Oyediran (eds) Transition Without End, Ibadan: Vantage Publisher Ltd. 
Prince News (2010) Nigeria Civil War: 40 Years After (www.sunnewssonline.com).

Suberu, R. T. (1991) “The Struggle for New States in Nigeria, 1976-1996”

African Affairs, Vol. 1.

Suberu, R.T. (1998) "State Creation and the Political Economy of Nigerian

Federalism" in Kunle Amuwo et. al., (eds) Federalism and Political

Restructuring in Nigeria. Spectrum Books Limited and IFRA Ibadan.

Suberu, R.T. (1999) "Public Policies and National Unity" in Nigeria Research

Report, No 19 Development Policy Centre, Ibadan Nigeria.

Ukiwo, U (2007) "Creation of Local Government Areas and Ethnic Conflicts in

Nigeria: A Case of Warri Delta State (wnw.linkinghub.elsevier.com). 